\title{
Atmospheric Deposition of Sulfur, Nitrogen and basic Cations onto European Forests : Observations and Model Calculations
}

\section{Ivens, W.}

Springer

1989

Ivens, W. et al. 1989. Atmospheric Deposition of Sulfur, Nitrogen and basic Cations onto European Forests: Observations and Model Calculations (Chapter 9 in Regional Acidification Models, Geographic Extent and Time Development): 103-111

http://hdl.handle.net/1975/327

Downloaded from Helda, University of Helsinki institutional repository.

This is an electronic reprint of the original article.

This reprint may differ from the original in pagination and typographic detail.

Please cite the original version. 


\section{Chapter 9}

\section{Atmospheric Deposition of Sulfur, Nitrogen and Basic Cations onto European Forests: Observations and Model Calculations}

Wilfried Ivens ${ }^{1}$, Albert Klein Tank ${ }^{1}$, Pekka Kauppi ${ }^{2}$ and Joseph Alcamo

\section{Summary}

Measurements of sulfur and nitrogen deposition by means of the throughfall method are compared with model estimates. The sulfur model appears to estimate deposition to deciduous forests very well, but underestimates deposition to conifers by 30 to $40 \%$. The $\mathrm{NH}_{4}-\mathrm{N}$ deposition to forest is underestimated by the applied model. The model predictions of $\mathrm{NO}_{3}-\mathrm{N}$ deposition do not show any bias against observations, but are not better correlated with observations than $\mathrm{NH}_{4}$ calculations. Reduced nitrogen compounds are the dominant nitrogen form in throughfall in ammonia polluted areas and contribute up to $50 \%$ of the total nitrogen deposition in other areas. Deposition of alkaline material to forests is estimated by applying different methods. Basic cation deposition neutralizes about $31 \%$ of the acid sulfur deposition to forest, on the average. Because of the large spatial variability of base cation deposition, it is recommended to develop a model for atmospheric transport and deposition of calcium- and magnesium-bearing particles.

\section{Introduction}

To assess the ecological impact of atmospheric pollutants on ecosystems, it is necessary to quantify the input of these pollutants. Long range transport models are used to quantify this input at a European scale. These kinds of models have a coarse spatial resolution. Thus surface characteristics like the aerodynamic surface roughness are averaged over large grid elements $\left(>10000 \mathrm{~km}^{2}\right)$. Forested areas might filter more pollutants than non-forested areas, because of the greater surface roughness and greater total receptor

\footnotetext{
${ }^{1}$ Dept. of Physical Geography, Univ. of Utrecht, P.O. Box 80.115 Utrecht, The Netherlands

${ }^{2}$ Ministry of the Environment, P. O. Box 399, SF-00121 Helsinki, Finland

${ }^{3}$ International Inst. for Applied System Analysis, A-2361 Laxenburg, Austria
} 
surface of forests compared with other kinds of vegetation. Therefore long range transport models might underestimate atmospheric deposition onto forests. The aim of this study was to analyze deposition measurements and model results thereby estimating sulfur and nitrogen deposition onto forests in Europe. We also wished to account for the deposition of alkaline compounds, because of their neutralizing effect on acidifying processes.

In this study observed deposition fluxes obtained from the literature were compared with deposition estimates from long range transport models. The model estimates were provided by the International Institute for Applied System Analysis (IIASA, Austria).

The analysis of the sulfur deposition given in this paper is a simplified version of an analysis given in Ivens et al. (in press).

\section{Method}

This study focuses on element fluxes to the forest floor by canopy drip and stemflow. Canopy drip is the water dripping from the canopy during rainfall and stemflow is the water descending the trunk or stem. The sum of these fluxes, henceforth referred to as throughfall flux, includes both wet and dry deposition.

At the canopy-atmosphere interface chemical interactions can take place involving transfer of gases or particulate matter (absorption or release by the canopy). When irreversible uptake of an element from the atmosphere by the canopy occurs, throughfall fluxes will underestimate total atmospheric deposition of this element. Conversely throughfall fluxes will overestimate total atmospheric deposition when an element is excreted by the tree tissue.

Allthough leaves are capable of absorbing $\mathrm{SO}_{2}$, the major part of it will be leached from the leaf during rainfall (Bredemeier 1987). The internal flux of sulfur is insignificant $(<5 \%$ ) (Ulrich 1983; Lindberg et al. 1986; Garten et al. 1988) in conditions like in Central Europe, where the total deposition to the canopy is high, but might be of greater relative importance in remote areas.

In nitrogen deficient systems with low nitrogen deposition, a significant part of the nitrogen deposition can be absorbed irreversibly by the canopy (Grennfelt et al. 1987). In these systems throughfall fluxes will underestimate total nitrogen deposition. A substantial part of the calcium and magnesium flux in throughfall is thought to be caused by internal cycling of these elements (Parker 1983). Therefore atmospheric deposition of these elements will be less than the amount measured in the throughfall flux. To determine the magnitude of the atmospheric deposition of basic cations to forests, three approaches were used (Table 9.1 ):

- "minimum approach": it is assumed that basic cation deposition to forest takes place only by gravitational settling and by wet deposition; therefore deposition of alkaline particles to the forest equals deposition to other surfaces like bulk precipitation samplers

- "maximum approach": it is assumed that no significant leaching of calcium and magnesium from the plant tissue occurs; therefore throughfall flux of basic cations equals total deposition of these elements

- "filtering approach": it is assumed that the forest filtering of sodium-bearing particles is equal to the filtering of alkaline particles (Ulrich 1983) 
A total of 27 publications were evaulated. They described the sulfate-flux at 54 sites, the nitrate-flux at 51 sites, the ammonium-flux at 36 sites, the calcium-flux at 47 sites and the magnesium-flux at 38 sites (Figure 9.1). All measurements were done between 1967 and 1987. Duration of the measurements varied from a few months to more than 10 years. If the measurement period was shorter than one year the fluxes were ex-trapolated to annual fluxes. The fluxes were corrected for the contribution of sea-salt particles, using sodium and chloride (depending on which was available) as seasalt tracers (Asman et al. 1981).

Estimates for sulfur emission were computed to correspond to the years of the throughfall measurements by means of the RAINS model (Alcamo et al. 1987) currently used at IIASA. The impact of these emissions to the total deposition at the forest sites was estimated based on the average annual transport pattern provided by the runs of the EMEP II long range transport model for the years 1979, 1980, 1983 and 1984 (Lehmhaus et al. 1986).

Emission of nitrogen oxides was based on country emissions from Semb and Amble (1981) with the same spatial distribution as for $\mathrm{SO}_{2}$ in Dovland and Saltbones (1979). These emission estimates cannot be related to a particular year, but refer to emissions in the mid-to late-70s. Transport of $\mathrm{NO}_{x}$ was decribed based on results of a simplified version of the "Harwell" non-linear model (Derwent 1986; Derwent et al. 1986; Alcamo et al. 1988). Wind roses based on 1981 and 1982 sector analysis were used. The $\mathrm{NO}_{x}$ model used in this paper is in an earlier stage of development than the models used for $\mathrm{SO}_{2}$ and $\mathrm{NH}_{x}$ calculations. Therefore calculations of $\mathrm{NO}_{x}$ deposition have a lower reliability than for $\mathrm{NH}_{x}$ and sulfur. An improved version of this $\mathrm{NO}_{x}$ model, using more intensive meteorological measurements from 1980 and improved emission data, has been developed (Bartnicki and Alcamo under review), but was not available for this publication.

The $\mathrm{NH}_{3}$ emissions were taken from Buijsman et al. (1986), who refer to emissions in the first part of the $80 \mathrm{~s}$. The $\mathrm{NH}_{x}$ deposition model is based on the results of the "IMOU/ECN"-model (Asman et al. 1987; Alcamo et al. 1988) using 1980 meteorology.

In this paper we did not use emissions from years corresponding the deposition measurement years of either $\mathrm{NO}_{x}$ or $\mathrm{NH}_{x}$. This adds an additional uncertainty to the $\mathrm{N}$ calculations compared to the sulfur calculations.

Only the model estimates of concentrations in air and precipitation have been validated. No validations of total and dry deposition estimates have been carried out, because of the unavailability of data.

\section{Results}

\section{Sulfur}

The model predicted deposition onto deciduous forests very well, without significant bias (Figure 9.2). The ratio between calculated and observed values was $1.0 \pm 0.3$, calculated fluxes being not significantly different from the throughfall fluxes. The coefficient of determination $\left(\mathrm{r}^{2}\right)$ between observations and model estimates was 0.76 . The model underestimated deposition onto coniferous stands (Figure 9.3). The observed throughfall fluxes at these stands were $1.6 \pm 0.8$ times greater than the model estimates; the difference between calculated and observed values was statistically significant. The coefficient of determination $\left(\mathrm{r}^{2}\right)$ between calculations and observations was 0.43 . The mean sulfur flux 
Table 9.1. Three options to calculate deposition of basic cations $(B C)$ to forest from bulk precipitation $(B P)$ and throughfall $(T F)$ measurements. Bulk precipitation = total deposition to funnels situated in clearings. $(C a+M g)_{b p}=$ calcium +magnesium bulk precipitation flux; $N a_{t f}=$ sodium throughfall flux; $N a_{b p}=$ sodium bulk precipitation flux.

\begin{tabular}{lc}
\hline approach & formula \\
\hline minimum & $B C=B P$ \\
maximum & $B C=T F$ \\
filtering & $B C=(C a+M g)_{b p} *\left(N a_{t f} / N a_{b p}\right)$ \\
\hline
\end{tabular}

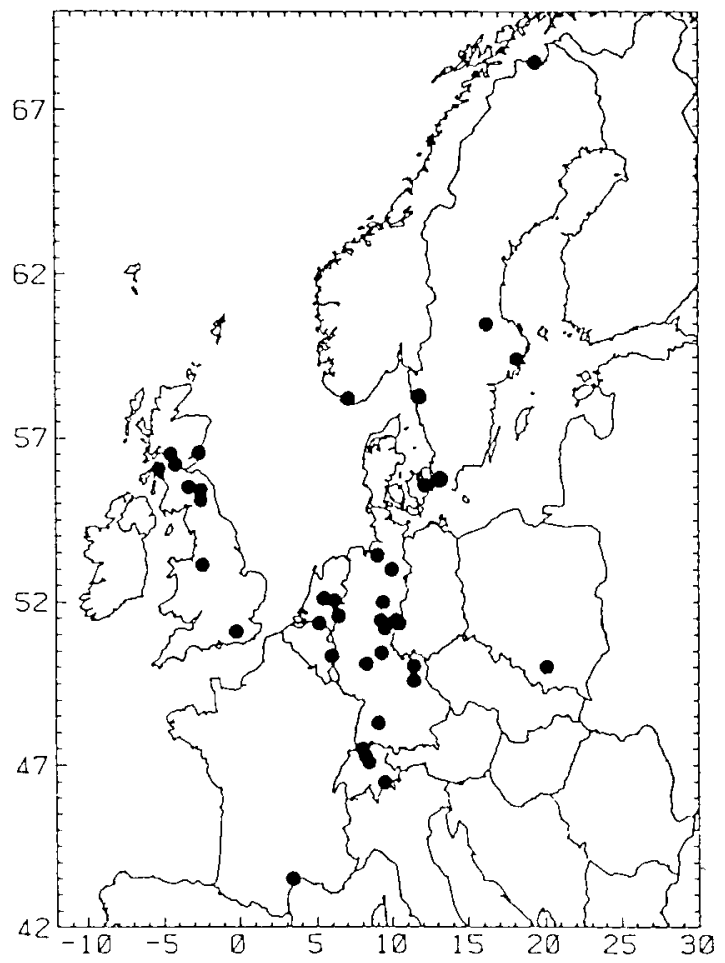

Figure 9.1. Location of the measurement sites. Several sites are located within a few $\mathrm{km}$ distance from each other. In such cases only one site is indicated on the map. 


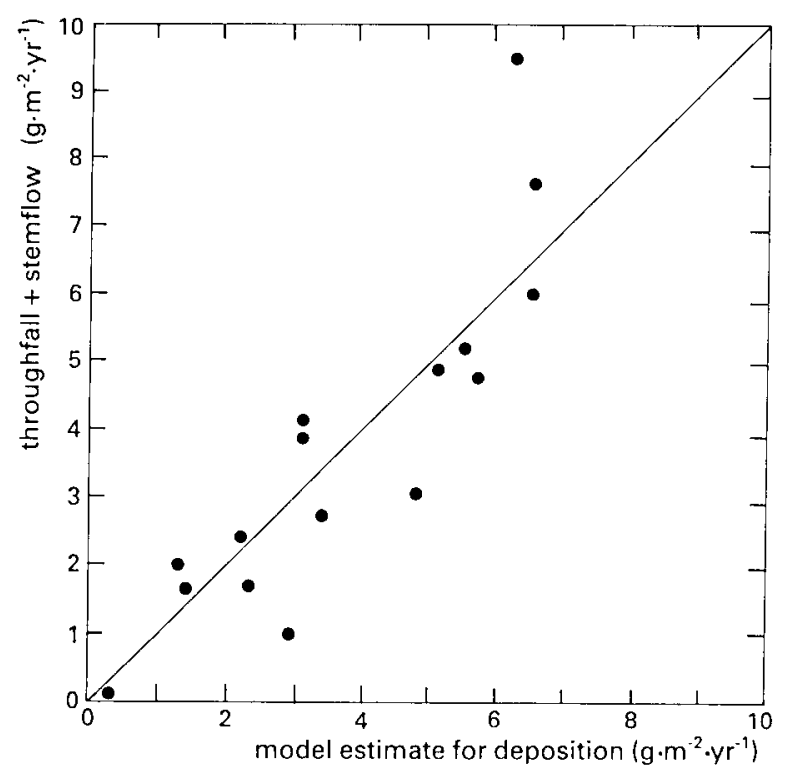

Figure 9.2. Model estimates of sulfur deposition versus sulfur flux onto the forest floor in deciduous stands.

in throughfall at the measurement sites was $4.2 \pm 2.3 \mathrm{~g} \mathrm{~m}^{-2} \mathrm{yr}^{-1}$.

\section{Nitrogen}

Throughfall of $\mathrm{NH}_{4}-\mathrm{N}$ appeared to be on an average $1.7 \pm 1.5$ times greater than model estimates (Figure 9.4). The difference between observed and calculated deposition was significant. The coefficient of determination was 0.35 . In particular at sites in $\mathrm{NH}_{4^{-}}$ $\mathrm{N}$ polluted areas model predictions are much to low. This probably is due to the big influence of dry deposition of $\mathrm{NH}_{3}$ in such sites.

On the average there was no significant difference between observations and model estimates for $\mathrm{NO}_{3}-\mathrm{N}$ deposition (Figure 9.5). The ratio between observations and calculations was $1.0 \pm 0.6$ for $\mathrm{NO}_{3}-\mathrm{N}$. The coefficient of determination between calculations and observations was 0.42 .

It has to be emphasized that throughfall fluxes might be underestimates of the total atmospheric nitrogen deposition, because of irreversible assimilation of nitrogen by the canopy. Therefore we expected both $\mathrm{NH}_{4}-\mathrm{N}$ and $\mathrm{NO}_{3}-\mathrm{N}$ calculations to exceed throughfall measurements. Because this is clearly not the case in figures 9.4 and 9.5, either this canopy absorption was not significant in these measurements, model calculations are not sensitive enough to pick up this effect, or dry deposition is relative great.

The mean $\mathrm{NH}_{4}-\mathrm{N}$ and $\mathrm{NO}_{3}-\mathrm{N}$ deposition in throughfall fluxes were, respectively, $2.5 \pm 2.6$ and $1.1 \pm 0.7 \mathrm{~g} \mathrm{~m}^{2} \mathrm{yr}^{-1}$. The ammonium fluxes are extremely high at the measurement sites in the Netherlands. The mean $\mathrm{NH}_{4}-\mathrm{N}$ throughfall flux was $5.4 \pm 2.7$ at the Dutch sites $(\mathrm{n}=11)$ and $1.2 \pm 1.1 \mathrm{~g} \mathrm{~m}^{-2} \mathrm{yr}^{-1}$ at the other European sites $(\mathrm{n}=25)$. The contribution of $\mathrm{NH}_{4}-\mathrm{N}$ to the total nitrogen fux in throughfall was $76 \pm 7 \%$ in the Netherlands, and $50 \pm 14 \%$ in the rest of Europe. 


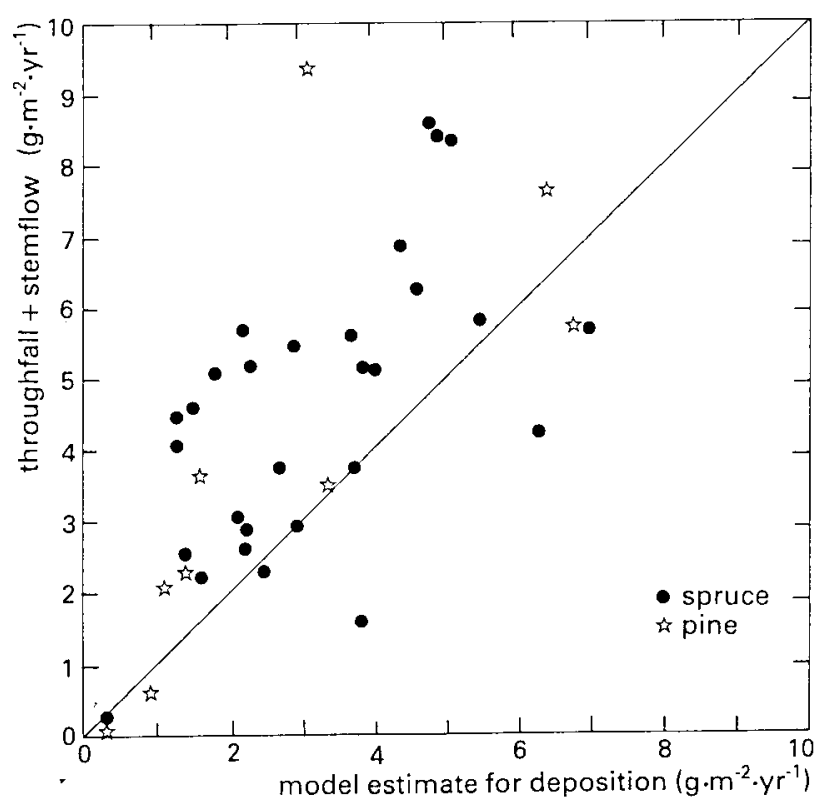

Figure 9.3. Model estimates of sulfur deposition versus sulfur flux onto the forest floor in coniferous stands.

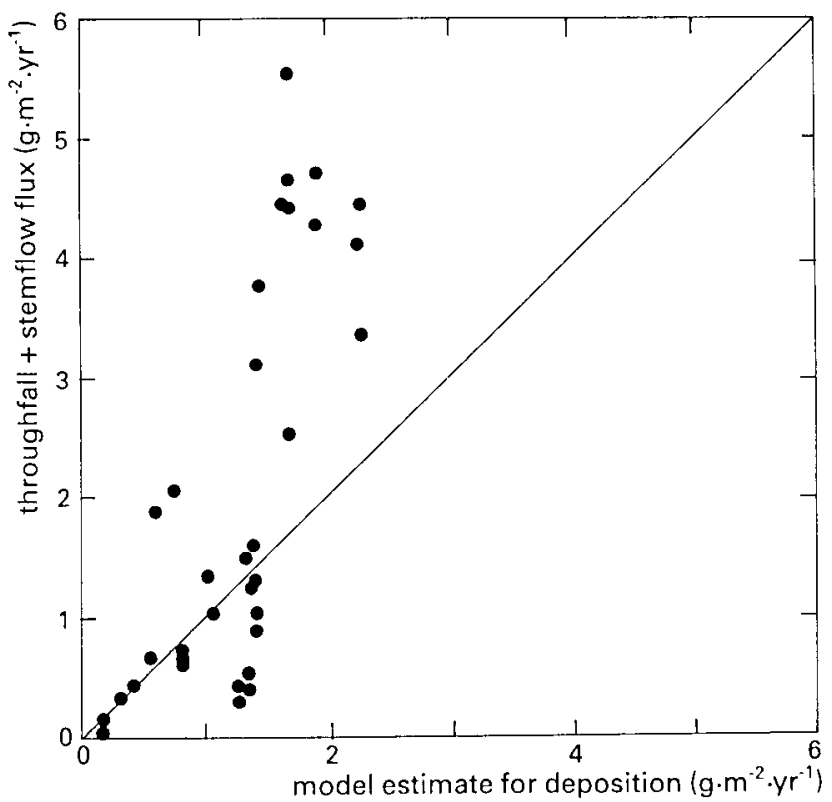

Figure 9.4. Model estimates of $\mathrm{NH}_{x}-\mathrm{N}$ deposition versus $\mathrm{NH}_{4}-\mathrm{N}$ flux onto the forest floor. 


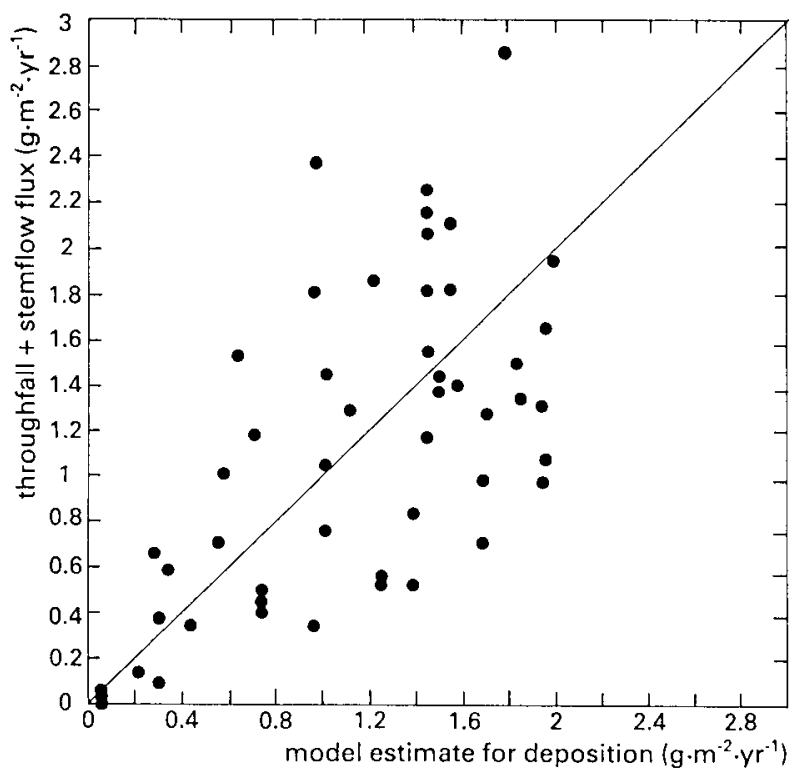

Figure 9.5. Model estimates of $\mathrm{NO}_{x}-\mathrm{N}$ deposition versus $\mathrm{NO}_{3}-\mathrm{N}$ flux onto the forest floor.

Table 9.2. Mean deposition of calium+magnesium to forest $(B C)$, applying 3 different approaches (meq $\mathrm{m}^{-2} \mathrm{yr}^{-1}$ ).

\begin{tabular}{lc}
\hline approach & $B C$ \\
\hline minimum & $34.3 \pm 14.0$ \\
maximum & $116.3 \pm 37.0$ \\
filtering & $85.8 \pm 35.1$ \\
\hline
\end{tabular}

\section{Basic Cations}

Calculation of the mean atmospheric basic cation deposition at the studied forests gives clearly different results, depending on the method applied (Table 9.2). Using present day knowledge, the filtering approach is the best estimate for atmospheric deposition of basic cations. The other two approaches show the limits of uncertainty. The fraction of sulfur deposition neutralized by basic cation deposition $(\beta)$ was calculated to evaluate the relative importance of the neutralizing effect of the alkaline substances:

$$
\beta=B C / S
$$

where $B C$ is the basic cation deposition (meq $\mathrm{m}^{-2} \mathrm{yr}^{-1}$ ) and $S$ is the sulfur deposition (meq m $\mathrm{m}^{-2} \mathrm{yr}^{-1}$ ).

The neutralizing fraction is substantial. In $81 \%$ of the forests $\beta$ was between 0.20 and 0.50 . The median $\beta$ was 0.31 . There appeared to be no significant difference between coniferous and deciduous stands. 


\section{Discussion and Conclusions}

As the RAINS/EMEP model underestimates $S$ deposition onto coniferous stands, correction coefficients may be needed to assess the deposition onto areas where conifers are the main tree species.

The $\mathrm{NH}_{x}$ deposition model underestimates $\mathrm{NH}_{x}$ deposition onto forests, especially in areas with intensive husbandry. The $\mathrm{NO}_{\boldsymbol{x}}$ model at IIASA is currently being improved; a new version of the model will have more detailed information about meteorology and emissions.

The mean input of $\mathrm{SO}_{4}, \mathrm{NH}_{4}, \mathrm{NO}_{3}$ and $\mathrm{Ca}+\mathrm{Mg}$ to the forest soils at the studied sites by throughfall was respectively $260,100,80$ and $86 \mathrm{meq} \mathrm{m}^{-2} \mathrm{yr}^{-1}$. Because of the particular situation of extreme ammonia emissions in the Netherlands, all Dutch sites together were treated like 1 site in the calculation of the mean $\mathrm{NH}_{4}$-flux. It should be noted that the mean sulfur and nitrogen throughfall fluxes, are representative for western and central European conditions. Throughfall fluxes in remote areas like Northern Scandinavia, Turkey and parts of Russia, will be substantially lower for both sulfur and nitrogen.

A very important part of the nitrogen input of forested ecosystems all over Europe is in the form of ammonia and ammonium. Therefore much attention should be given to the role of reduced nitrogen components in impact models dealing with nitrogen saturation of ecosystems.

The long range transport of alkaline particles often is considered of minor importance, because of the assumed large diameter of such particles. However this study shows that basic cation deposition can not be neglected in acidification models. A model should be developed for atmospheric transport and deposition of calcium- and magnesium-bearing particles. It is not possible to link basic cation deposition directly to acid deposition because sources of atmospheric basic cations (soil and road dust, agricultural fertilizers, quarries, burning of fuels) are mainly different from sources of acidic compounds. Therefore it is neccessary (1) to identify the basic cation sources, (2) to determine the typical particle size of the compounds emitted at each source type, (3) to quantify the amount and distribution of the emission on an European scale and (4) to analyze the transport capability of basic cation particles. Considering long range transport of alkaline particles the influence of events (such as storms) should be analyzed.

\section{References}

Alcamo, J., Amann, M. Hettelingh, J.-P., Holmberg, M., Hordijk, L., Kämäri, J., Kauppi, L., Kauppi, P., Kornai,G. and Mäkelä, A.: 1987, Ambio 16, 232

Alcamo, J. and Bartnicki, J.: 1988, Nitrogen deposition calculations for Europe, WP-88025, International Institute for Applied System Analysis, Laxenburg, Austria

Asman, W.A.H. and Janssen, A.: 1987, Atmos. Environ. 21, 2099

Bartnicki, J. and Alcamo, J.: under review, Calculating $\mathrm{N}$ deposition in Europe Water Air Soil Pollut.

Asman, W.A.H., Slanina, J. and Baard, J.H.: 1981, Water Air and Sail Pollut. 16, 159

Buijsman, E., Maas, J.M. and Asman, W.A.H.: 1987, Atmos. Environ. 21, 1009 
Derwent, R.G.: 1986. The nitrogen budget for the United Kingdom and Northwest Europe. ETSU-Report-37, ETSU, Harwell, Oxfordshire, United Kingdom

Derwent, R.G. and Nodop, K.: 1986, Nature 324, 356

Dovland, H. and Saltbones, J.: 1979, Emission of sulfur dioxide in Europe in 1978. EMEP/CCC-report 2/79, NILU, Oslo, Norway

Garten, C.T., Bondietti, E.A. and Lomax, R.D.: 1988, Atmos. Environ. 22, 1425

Grennfelt, P. and Hasselrot, B.: 1987, 'Deposition of ammonium and nitrate to forest edges', in W.A.H. Asman and H.S.M.A. Diederen (eds.), Proceedings of the Eurasap symposium "Ammonia and acidification", Bilthoven (The Netherlands), April 13-15, 1987, pp 124-140

Ivens, W., Kauppi, P., Alcamo, J. and Posch, M.: in press, 'Empirical and model estimates of sulfur deposition onto European forests'. Tellus

Lehmhaus, J., Saltbones, J. and Eliassen, A.: 1986, A modified sulfur budget for Europe for 1980. EMEP/MSC-W Report 1/86, NILU, Oslo, Norway

Lindberg, S.E., Lovett, G.M., Richter, D.D. and Johnson, D.W.: 1986, Science 231, 141

Parker, G.C.: 1983, 'Throughfall and stemflow in the forest nutrient cycle', in A. MacFadyen and E.D. Todd (eds.), Advances in ecological research, Vol. 13, pp. 58-121

Semb, A. and Amble, A.: 1981, Emission of nitrogen oxides from fossil fuel combustion in Europe. ISBN-82-7247-277-5, Norwegian Institute for Air Research, Lilleström, Norway

Ulrich, B.: 1983, 'Interaction of forest canopies with atmospheric constituents: $\mathrm{SO}_{2}$, alkali and earth alkali cations and chloride', in B. Ulrich and J. Pankrath (eds.), Effects of Accumulation of Air Pollutants in Forest Ecosystems, Reidel, Dordrecht, The Netherlands, pp $33-45$ 